Article

\title{
Going Public and Industrial Upgrading of Traditional Clusters in Developing Countries: Rethinking the Dynamics of the 'Jinjiang Model' in China
}

\author{
Huasheng Zhu ${ }^{1,2, *}$ and Yue Ding ${ }^{2}$ \\ 1 The State Key Laboratory of Earth Surface Processes and Resource Ecology, Beijing Normal University, \\ Beijing 100875, China \\ 2 Faculty of Geographical Science, Beijing Normal University, Beijing 100875, China; dingyue678@hotmail.com \\ * Correspondence: zhuhs@bnu.edu.cn; Tel.: +86-10-5880-0193
}

Received: 24 September 2017; Accepted: 24 September 2017; Published: 19 November 2017

\begin{abstract}
Extant literature concerns about industrial upgrading in developing countries, and stresses the importance of joining global production networks (GPN). Taking the perspective of the updating approach of GPN theory, this paper selects the case of China to combine local industrial upgrading with financial activities, and explores how going public triggers industrial upgrading in developing countries. In 2015, semi-structured interviews were conducted with 36 listed firms and their related partners in Jinjiang, a county-level city in China. The findings indicate that local lead firms in developing countries have been increasingly involved in the global financial market by going public, which in turn provides these countries with opportunities of industrial upgrading. However, it does not necessarily guarantee industrial upgrading. Whether or not going public can bring about industrial upgrading depends mainly on intrafirm coordination, reconfiguration of interfirm relationships, and extrafirm bargaining with local governments. This case study suggests that finance be integrated into GPN theory as some scholars suggest, and the impacts of local lead firms in developing countries on the dynamics or reconfiguration of GPN be taken consideration, especially in some specific sectors.
\end{abstract}

Keywords: going public; listed firms; industrial clusters; industrial upgrading; global production networks

\section{Introduction}

Since its reform and opening-up in the late 1970s, China has made a great expansion in manufacturing sectors, and has created the miracle of "made in China". China exceeded the United States in the output value of its manufacturing for the first time in 2010, and the country has maintained its position as the world's leading manufacturing country since then [1]. However, many manufacturing firms in China have integrated into global production networks (GPN) through original equipment manufacturers (OEM) with a low level of profit, and only a few can realize an upgrading towards being original design manufacturers (ODM) or original brand manufacturers (OBM). Actually, China has encountered the serious challenge of two-way extrusion: the manufacturing reflux and re-industrialization in developed countries since the 2008 subprime crisis, and increasing competition for low-end manufacturing in developing countries. It is thus urgent to consider how to succeed in achieving industrial upgrading and avoiding industrial "hollowing-out".

Industrial upgrading in developing countries attracts a great deal of academic attention [2,3]. The extant literature is concerned with upgrading at the national level, mainly about the enhancement of industrial competitiveness in the world [4]. Other studies focus on the firm level, and discuss how lead firms in developing countries can turn to be a global leader [5]. Researchers rarely 
focus on industrial upgrading in a specific region within a developing countries with integration into GPN. Therefore, this article explores industrial upgrading under the context of local clusters. Moreover, the extant literature stresses the importance of joining GPN in the process of industrial upgrading, mainly through technological accumulation and innovation and knowledge learning [6-8], but takes little consideration about the effects of financial activities on industrial upgrading. Actually, financial activities can provide firms with external capital support for reorganizing production, and enhancing competitiveness and innovation [9-12]. As the global financialization increases, the process of production and financialization gradually become interrelated [13]. More and more local firms in developing countries tend to make connection with external capital markets [14]. As a way to link with global capital networks, going public can provide firms with a financial advantage to make up for a lack of bank credit and financing capacity [12], to gain access to global capital and knowledge, and to promote the development of industrial clusters [11,15].

However, the research about financial activities provides little discussion of its connection to industrial upgrading. Industrial upgrading research and GPN theory neglects that finance has a significant impact on regional industrial development $[14,16]$. Yeung and Coe suggest that a complete GPN theory should take into account the causal role of finance in disciplining the organization of capitalist production. Financial discipline has become important in the environmental and competitive dynamics that shape a firm's strategies, and in (re)configuring to GPN, which can be used to explain industrial upgrading [17]. Therefore, this article provides a case in China, combines industrial upgrading of local clusters with financial activities, and aims to explore whether going public of local firms can trigger the industrial upgrading of clusters in developing countries.

The remainder of the article is structured as follows. The second section makes literature review on the relationships of GPN, financial activities, and industrial upgrading, and establishes the analytical framework of this article. The third section introduces the research area and methodology, and the fourth part makes an exploration to the case of Jinjiang, a county-level city in the coastal area of Southeastern China. The fifth part draws conclusions and discussion for further research.

\section{Literature Review and Analytical Framework}

\subsection{GPN and Financial Activities}

The concept of GPN was first proposed by Ernst [18], and Henderson, Dicken, Hess, et al. [19]. A GPN is an organizational structure that combines the value chain across the boundaries of the firm and national borders with network participants through a parallel process of integrating hierarchical layers [6]. The existing GPN theory ('GPN1.0' in Yeung and Coe's words) emphasizes its governance typologies (e.g., modular, relational, and captive modes in GPN theory) or analytical categories (e.g., power and embeddedness in GPN) [20,21], in addition to the integration with global networks and the role of global lead transnational companies (TNCs) [22].

However, GPN 1.0 theory overlooks the fact that a GPN evolves dynamically with time and changing environments. Therefore, Yeung and Coe put forward the GPN 2.0 theory, which went beyond the narrow focus on interfirm governance structures in the GPN, proposing an actor-centered conceptualization [17]. They conceptualize competitive dynamics, including optimizing cost-capability ratios, sustaining market development, and working with financial discipline within the broader risk environments, to reshape firm strategies (intrafirm coordination, interfirm relationships, and extrafirm bargaining). These dynamics and strategies collectively co-constitute the causal mechanisms of a GPN, which can explain some empirical economic developmental outcomes, such as firm growth, technological innovation, industrial upgrading and sectoral transformation, and local and regional development.

Since the 1970s, as more and more savings and credit have been inserted into financial markets, firms do not need to rely solely on banks to subsidize their funding gaps. Turning to capital markets can be an alternative and complementary way for firms to meet their investment needs, which they 
need to fulfill their investors' financial goals, since they are interested in higher short-term stock prices [17]. Under the context of global financialization, finance has become an increasingly important driver of GPN structures and strategies.

However, the current research underestimates the role of financial capital and the financial sector in shaping global production systems and it requires a deeper understanding of "the impacts of financialization at the sectoral and corporate level on GPN structures and dynamics" [23]. Coe et al. put forward the concept of Global Financial Networks (GFN) and intend to examine how finance shapes the entire operation of the global production of manufactured products [24]. They believe that finance mainly affects the GPN in three areas. First, it is implicit that funds are transferred from buyers to suppliers through a network of relationships in the GPN. Second, great changes have taken place in the external funding environment, which will reshape the activities of firms in GPN to maximize their benefits. As lead firms in GPN increasingly operate within a global financial environment, there is an impact on the firms themselves and on how they seek to construct and configure the GPN. Third, financial actors play a central role in the construction of GPN structures. Firms in a variety of other advanced business services are heavily involved when a focal firm seeks to establish its business in a host economy. As Yeung and Coe noted, a complete GPN theory should take into account the causal role of finance in disciplining the production organization in the global economy [17]. In addition, financialization addresses the ways in which multi-national enterprises and wider GPN are increasingly controlled, monitored, and disciplined by financial markets, via such notions as shareholder value, calculation of risk, and market perception of mergers and acquisitions (M \& A) [25]. In order to maintain profits and provide value for shareholders, companies may change the direction of their development and their strategies to maximize the interests of their investors [14], and to disintegrate their production vertically and internationally [26]. However, the analytical framework of the GPN 2.0 theory still pays attention to global leaders rather than local lead firms in industrial clusters of developing countries, not to mention the effects of their financial activities on the industrial upgrading of local clusters in those countries.

\subsection{Financial Activities and Industrial Upgrading of Locall Clusters in the Context of GPN}

The concept of industrial upgrading has been studies at enterprise and sectoral scale. Enterprise upgrading is the micro base of industrial upgrading. According to Humphrey and Smith [27], Gerrifi [2], and Kaplinsky and Morris [28], for a single firm, upgrading is essentially a process of continuous improvement of the skill content of their activities and/or moving into market niches that have entry barriers. As a result, it improves the competitiveness and realize the ascending process from low value added links of value chain to high value added links in GPN. There are usually four types, namely, process upgrading, production upgrading, functional upgrading, and chain upgrading. Industrial upgrading is the process of improvement of the ability and autonomy of the overall industry [2]. As far as a region, industrial upgrading means dominant industries increasingly depend on advanced factors, such as financial and human capital, technology, rather than labor, and natural resources [29]. Inside the manufacturing industry, upgrading also means the transformation from labor-intensive sectors to capital-, technology-, or knowledge-intensive sectors [3].

As mentioned above, the extant research calls for the combination of finance and GPN. However, finance has a broad content, covering financial actors, markets, and practices [24]. It is feasible to focus on a couple of financial activities, such as going public, at the beginning.

(1) Going public, intrafirm coordination, and upgrading of local firms

Under an open economy and globalization, it is believed that industrial upgrading has a connection with GPN. As suggested by Ernst and Kim, GPN offer opportunities for suppliers in developing countries to make use of international knowledge transfer to expand the scope of their industrial upgrading [6]. Moreover, the high-level quality requirements of global lead firms have driven local suppliers to upgrade production technology and improve management capability. Additionally, 
GPN 2.0 theory concerns about the role of intrafirm coordination strategies in the dynamics of GPN [17]. Intrafirm coordination refers to the internalization and consolidation of value activity, including outsourcing production, management optimization, product innovation, and technological upgrading, in order to achieve greater firm-specific efficiencies, such as lower inventories and cost control, greater market responsiveness, and higher-quality products or services [17]. This process is really related to industrial upgrading, and it would enhance the status of firms in the GPN.

Going public sets up a link of a firm with a global financial network. It makes a firm exposed to and responsd quickly to the changing circumstances of the global market. The intrafirm coordination of listed firms is guided and controlled through the stock price by investors and shareholders in the capital market. First of all, in order to be listed successfully on a specific stock exchange at a specific destination, local firms have to make adjustments to meet the requirements, such as financial standards and regulatory systems [10]. That would be a way to improve internal management efficiency and capability for a firm, which need further considerations. Secondly, listed firms have to contrive to perform well in terms of their stock prices and executive rewards, because shareholders and investors pay attention to greater profits from a firm's strategies. That prompts listed firms to shift their strategies towards a finance-driven approach [30,31]. As a result, these firms tend to make adjustment in organizational structure and corporate strategy, in order to satisfy consumers in the market and professional fund managers [23]. Furthermore, relevant research shows that stock price fluctuation is closely linked with technological innovation, and the stock market has an incentive to innovative activities $[32,33]$. It proves that listed firms focusing on technological innovation can get a better performance, because there is information feedback on technological innovation in capital market [34], and information of technological innovation gives investors an important reference, which will eventually affect the stock price.

Going public provides a firm with financial resources for intrafirm coordination. Taking going public as a response to the changing circumstance for long-term development, these firms tend to use the funds for the improvement of technical capacity [35,36], which is thought as a prerequisite of firm upgrading. In terms of Resource-Based View, the acquisition of crucial resources and competencies lay the foundation for firm upgrading [37], because firms can gain a competitive advantage by configuring valuable, scarce, and inimitable resources [38]. As an extension of Resource-Based View, the theory of Dynamic Capability emphasizes the role of dynamic capacities, namely, firms' abilities to integrate, build, and reconfigure internal and external competences, in the adaptation to technological and market changes, and thus strengthening their competitive advantage [39]. Such capacities are also based on the internal resources (such as skills, knowledge, and know-how) of firms, and their increase is time-consuming and expensive. From this perspective, increasing demand for crucial resources drives firms to establish external networks [40]. Going public could be a way to enter the global market and set up external networks.

In general, firms would choose some specific places for being listed where investors are familiar with and tend to invest in related businesses [41]. Industrial similarity to the listing destination facilitates listed firms to get funds and sets up a pipeline for them to obtain knowledge from these places [42]. Firms in developing economies have relied largely on local and regional bank loans or other informal financial networks as their major means of financing [43,44]. In particular, in China, state-owned financial institutions are particularly cautious about loans for private firms, and so these firms encounter difficulties in getting funds, and some have to fall back to global capital market through going public to get access to funds with a relatively low transaction cost. Interestingly, it becomes easy to get loans from domestic banks for private firms after being successfully listed abroad.

Going public can improve a firm's reputation and facilitate it to attract and retain talents [45]. Stokman et al. (1990) show that newly appointed directors often have high levels of professional knowledge and a wealth of practical experience [46]. It was also found that strategic investors and shareholders can link invested firms with other organizations, including universities and other large companies, and entrepreneurs [47], bringing more opportunities for knowledge acquisition and 
innovation for these firms. Moreover, private firms can quickly obtain some scarce resources that are monopolized by state-owned enterprises in developing countries at a lower cost through backdoor listing (mergers and acquisitions) [48], which can be taken as a practical way to enter a new industry and realize the chain upgrading.

(2) Going public, interfirm relationship and extrafirm bargaining, and industrial upgrading

Interfirm relationship contains interfirm control and partnership. According to theGPN 2.0 approach, financial disciplines, together with cost-capability based market competition and risk management, impose lead firms to control their suppliers and contractors, and to develop supplier capabilities for improving collective efficiency. Meanwhile, lead firms pay more attention to the cooperative relationships with their strategic suppliers, and producer services firms, in order to gain and strengthen their competitiveness in their GPN [17].

However, it does not mean that interfirm relationsips within GPN necessarily give opportunity of upgrading to suppliers and contractors. It may vary substantially in relation to firm-specific and country-of-origin attributes. Some evidence shows that because of being tightly controlled by global lead firms, the integration of local firms into the GPN cannot automatically bring about industrial upgrading in developing countries [6]. It is believed that industrial upgrading in developing countries can be motivated by the construction and reconfiguration of local production networks rather than GPN, and it depends on initiative strategies of the local lead firms in those countries $[49,50]$. As far as local networks, interfirm relationship is interpreted as an important channel for local firms to knowledge sharing and creation, which is related to the industrial upgrading of local clusters.

According to industrial cluster research, geographical and relational proximity contributes to formal and informal relationships and interactions between local firms [51], which bring about knowledge exchange and knowledge creation [52]. Listed firms in the cluster sets up a role model and their success in stock exchanges and business growth will subsequently drive other firms in the cluster to take the strategy of going public [42]. Furthermore, once listed firms make upgrading, their knowledge and information would be transferred to other firms in the cluster through formal or informal networks. In addition, firms, especially the lead firms in clusters, also often learn from external and even international strategic partners. They act as gatekeepers or knowledge brokers [53] for local clusters to link with external even global knowledge sources and get access to heterogeneous knowledge, which drives the growth and innovation of other firms inside the clusters through local buzz. Evidence shows that once one firm has successfully implemented a listing plan, information of capital markets and knowledge of how to access to external capital spreads quickly [54]. Firms tend to extend their relationships with other firms (in other sectors) in the local and beyond the cluster after going public. However, there is little attention to the effects of these intensified relationships on the upgrading of these firms and the local industry in the extant research and this issue deserves discussion.

GPN 2.0 approach points out the significant influence of nonfirm actors, such as the state, international organizations, labor groups, consumers, and civil society organizations, on shaping interfirm governance and the reconfiguration of GPN [17]. However, whether or how nonfarm actors promote industrial upgrading through financial activities has not yet been studied in detail. As far as developing countries, local governments are an important nonfirm actor, because it is an administrative institution to deal with market immaturity and failure and a public utilities and services provider in local production networks. One of the benefits for firms from going public is obtaining more bargaining power with and more supports from local governments [55], and then they can make market expansion and promote innovation. These behaviours would improve bargaining power with global lead firms to move up towards the knowledge-intensive links along the value chain and get more profits, which triggers their upgrading. It proves that cooperation among local governments, industrial associations, and firms promotes the optimization of local industrial environment, and guides firms to achieve innovation and functional upgrades [56]. In China, it is common for local governments to implement encouragement policies for local firms to be listed. This is partly because the number of listed firms is an indicator of local development [57]. 
Another reason why local governments are keen to encourage local firms to be listed is to obtain more stock allotment in the future [55]. The special fiscal decentralization system and political promotion tournament in China drive local officials to allocate scarce resources in favor of their administration performance. As Piotroski and Zhang (2014) pointed out, provincial governors would accelerate the process of going public before their promotion, and increase their political capital by raising the development of capital markets [58]. As a result, local governments provide support for (potential) listed firms through resource allocation, and they become interdependent.

To sum up, extant literature takes the perspective of GPN to explore industrial upgrading of developing countries. GPN theory pays attention to the global lead firms in developed countries, but neglects the role of finance and lead firms in developing countries in reconfiguration and dynamics of GPN and their role in industrial upgrading of developing countries. However, GPN 2.0 suggests taking consideration of finance, and provides an actor-center approach. Consequently, in the case study of Jinjiang, the authors draw upon the framework of GPN 2.0, in considering the impacts of going public of local firms on industrial upgrading from three aspects, namely, intrafirm coordination, interfirm relationships, and extrafirm bargaining.

\section{Research Area and Method}

\subsection{Research Area}

This paper uses empirical evidence from clusters in Jinjiang City, to test how going public affects the upgrading of individual firms and the overall clusters. We use Jinjiang as a typical case because it is famous for its listed companies, which became the highest number of all the counties in China, and represents an upgrading process from made to innovation. Jinjiang is a prefecture-level city in Fujian Province, and it is located in the coastal area of Southeast China (Figure 1). The city is a famous source of Chinese who have moved overseas, and its people began emigrating as far back as the Song and Yuan dynasties in China's history (960-1378 AD). At present, there are more than 200 million overseas Chinese from Jinjiang, with a relatively high concentration in Southeast Asian countries. Those kinship-based networks facilitate local residents' access to scarce resources, such as financial capital and the establishment of cooperative business relations with foreign countries. A large number of family-owned firms have been set up since China reformed and opened up in the late 1970s, bringing about the prosperity of traditional industrial clusters (the manufacturing cluster, in particular), with a typical feature of geographical distribution, namely, one town making one or two kinds of a specific product, such as clothing, umbrellas, and zippers. Jinjiang has transformed from an agricultural county into a manufacturing city, and an important off-shoring manufacturing destination in China, and thereby earning its designation as the "Jinjiang Model".

Jinjiang has retained a high-rate of economic growth, and the city has become the fifth in the top 100 counties in China since 2012. The manufacturing sectors in Jinjiang are traditionally mainly labor-intensive, and these sectors have been facing fierce competition from domestic and overseas markets. Recently, local government and firms have jointly tried to turn "Jinjiang manufacturing" into "Jinjiang Wisdom Manufacturing", through brand establishment, technological and institutional innovation, and plans for going public. Local industrial clusters, especially the shoes and apparel (S \& A) industry, achieved a significant industrial upgrading. Since $1995,80 \%$ of enterprises were OEM at the beginning, but in 2016, there are 137 national brands (42 was identified as Chinese well-known trademarks), ranking first in the county-level cities. Jinjiang won 14 national regional brands, such as "city of Jacket of the world", "National Sports Industry Base)", and "Chinese shoes". The total market share of the S \& A industry accounted for more than $60 \%$ of China. Among them, sports and travel shoes accounted for $40 \%$ of China, and $20 \%$ of the whole world, and their products have been exported to 163 countries and regions. When compared to that in 2009, the production efficiency in the textile and garment industry increased by about 30\% in 2013. Local S \& A manufacturing has extended to the link with high added value, such as research and development, fashion design, 
and brand marketing. Nowadays, there are more than 50 enterprise technology centers in Jinjiang. In 2016, Jinjiang shoe-making enterprises developed more than 3200 new products in total.

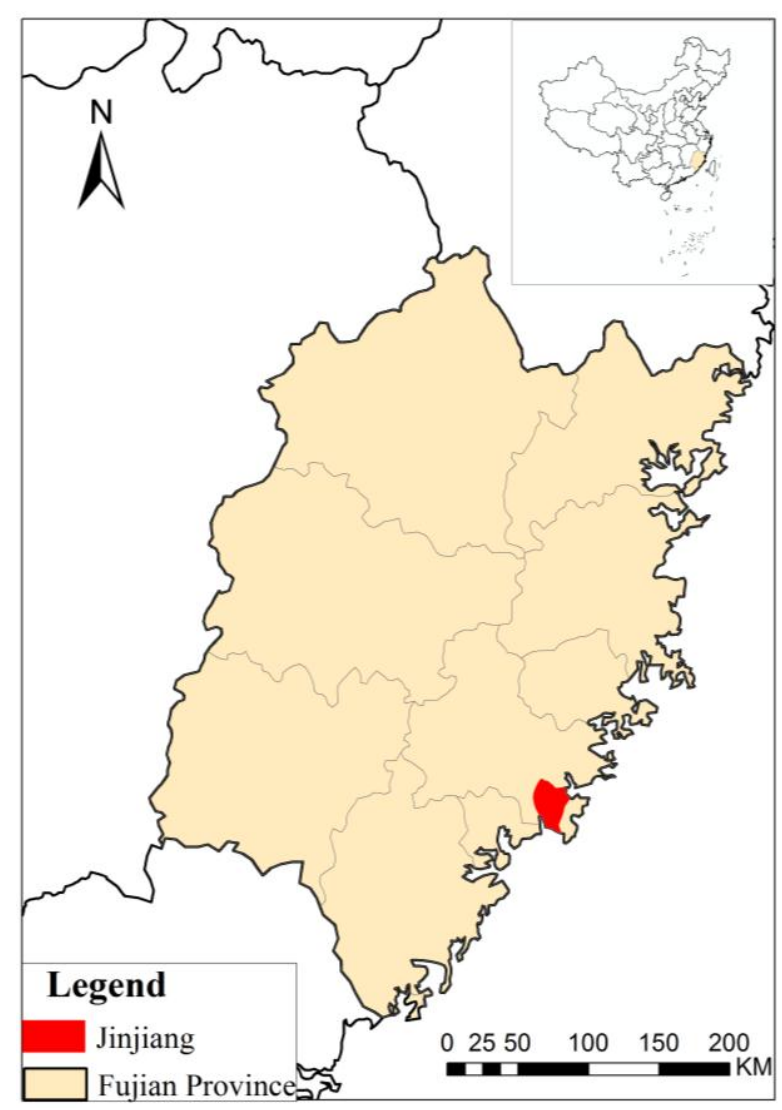

Figure 1. The location of Fujian in China and Jinjiang in Fujian.

Since the late 1980s, local firms began to go public, and the wave of being listed reached the peak in the late 2000s. At the end of 2016, there were 49 listed firms and 32 potentially listed firms in Jinjiang, this number ranking the top one among all of the counties in China. Listed firms are mainly concentrated in the traditional manufacturing industry. S \& A industry accounted for the highest proportion (74\%), followed by the food and beverage industry (6\%). $88 \%$ of firms are mainly listed abroad. Hong Kong is the top destination for going public, accounting for $33 \%$ of the listed firms, followed by Singapore (13\%), Malaysia (10\%), and the United States (US) (8\%). Consequently, the authors selected the city as a case to discuss whether or not going public can promote industrial upgrading.

\subsection{Research Methods}

This study selects the case of the S \& A industrial clusters in Jinjiang. The S \& A industry is a leading sector in the manufacturing of Jinjiang, with an output value exceeding 50 billion yuan, accounting for $50 \%$ of the total industrial output value. As mentioned above, nearly $74 \%$ of the listed firms in Jinjiang belong to this sector.

The case study adopted field interview for data collection. It included two rounds in total. The authors conducted an exploratory interview at the beginning, and derived this paper's focus from the responses of these initial interviewees. Once a clear research direction was identified, we conducted another round of follow up interviews to identify the different motives of going public and the firm strategies affected by going public. 
The first round of investigation was initiated in April 2015. During two weeks of extensive fieldwork, the S \& A industry was selected as the target sectors. Four S \& A firm owners, and five local government officials were interviewed to collect information about the history and status of the local $\mathrm{S} \& \mathrm{~A}$ industry, listing process, and the development of listed firms of this cluster. The interviewees were identified by personal recommendation, and they were highly respected in local professional fields. Each interview lasted a minimum of $45 \mathrm{~min}$.

The second round of survey was conducted in July 2015, and 50 firms were visited in total. This round of survey mainly aims to collect detailed information from local firms on the motivation of going public, constraints from going public, and the effects of going public on upgrading. In combination with Gereffi's definition of upgrading [28,59] and Tokatli's complementary viewpoint [60], five aspects are used to describe industrial upgrading, namely, profit rate, productivity, technological innovation, market share of products with own brands, and extension to links with a high level of added value in the value chain can be used. Before investigation in this stage, the basic information of all the 36 listed firms in Jinjiang S \& A industry has been gathered from government website. With the help of government officials, the authors completed the face-to-face interview of 30 listed firms. Based on the recommendations of these listed firms, the authors got a list of 35 related firms as their partners or competitors, and eventually eight of them firms accepted the invitation for an interview. Another six listed firms were investigated through online interview. Besides, through random visits on the main streets, the authors got the permission of six firms to participate in a semi-structured interview. Each interview lasted one hour or so, and all of the interviewees are corporate executives, who are familiar with the history and state of their firms. The main survey questions are shown in Table 1, and the basic information of these 50 interviewed firms is listed in Table 2. The authors use A1-36 to represent these interviewed firms and A37-50 to represent related firms). Key points from all of the interviews were recorded for repeated analysis. Other sources of data were collected including annual report of listed firms, working reports of local government, local newspapers, and television interview programs.

Table 1. Framework of the semi-structured interview.

\begin{tabular}{ll}
\hline \multicolumn{1}{c}{ Interviewee } & \multicolumn{1}{c}{ Main Questions } \\
\hline Local Government & $\begin{array}{l}\text { (1) policies that the government uses to support going public and the industrial } \\
\text { upgrading of firms; (2) reasons why the government chose to build the "Jinjiang } \\
\text { Board"; (3) impact of listed firms on local development and industrial upgrading }\end{array}$ \\
\hline Local industrial associations & $\begin{array}{l}\text { (1) measures that industrial associations take for going public, and the upgrading } \\
\text { of firms in the industry; (2) impact of listed firms on local development and } \\
\text { industrial upgrading }\end{array}$ \\
\hline Listed firms & $\begin{array}{l}\text { (1) reasons for firms to be listed; (2) environment and strategies changed by going } \\
\text { public and their effects; (3) impacts of being listed on the upgrading of firms; } \\
\text { (4) new requirements for other supporting firms after being listed }\end{array}$ \\
\hline Related firms & Effects of going public of lead firms on your firm's upgrading and on the local industry \\
\hline
\end{tabular}

Table 2. Basic information of the listed firms interviewed in Jinjiang.

\begin{tabular}{|c|c|c|c|c|c|}
\hline Year of Establishment & $\begin{array}{l}\text { Number of } \\
\text { Firms }\end{array}$ & $\begin{array}{c}\text { Year of Going } \\
\text { Public }\end{array}$ & $\begin{array}{c}\text { Number of } \\
\text { Firms }\end{array}$ & $\begin{array}{c}\text { Locations of Going } \\
\text { Public }\end{array}$ & $\begin{array}{c}\text { Number of } \\
\text { Firms }\end{array}$ \\
\hline Before 1990 & 4 & Before 1990 & 0 & Hongkong & 9 \\
\hline 1991-2000 & 20 & $1991-2000$ & 0 & Taiwan & 3 \\
\hline 2000-2010 & 11 & 2000-2010 & 22 & Singapore & 6 \\
\hline After 2010 & 0 & After 2010 & 14 & Malaysia & 4 \\
\hline $\begin{array}{c}\text { Number of employees } \\
\text { at the firm }\end{array}$ & $\begin{array}{l}\text { Number of } \\
\text { firms }\end{array}$ & & & Mainland of China & 6 \\
\hline$\leq 1000$ & 7 & & & Europe \& America & 6 \\
\hline $1001-5000$ & 24 & & & Other countries & 2 \\
\hline$>5000$ & 5 & & & Other countries & 2 \\
\hline
\end{tabular}




\section{Going Public and Upgrading of S \& A Industrial Clusters in Jinjiang}

The interview shows that $83 \%$ of S \& A firms went public for the capital resource, $77 \%$ for expansion of products with their own brands in the global market, and only four firms went public because of following lead firms in jinjiang. Their motivations are linked to their intrafirm coordination and inter-organizational relationships, which then affects upgrading of firms themselves and the whole clusters.

Among the 36 listed firms, 27 firms think that going public plays an important role in the firm upgrading. The performance of upgrading is mainly about product upgrading, process upgrading, and chain upgrading, which is mainly manifested in the improvement of production efficiency and technological innovation, the increase of market share, as well as the extension of the value chain.

\subsection{Going Public, Intrafirm Coordination, and the Upgrading of Local Firms}

More than $90 \%$ of local firms in Jinjiang are family-owned businesses, and their primitive capital mainly depends on remittances from overseas relatives. In the early start-up period, these family-owned firms had advantages in their small size, production flexibility, and fast response to the lower-level-quality demand. However, once the proportion of family members in the firms becomes overly large, investment in innovation is hindered for the sake of realistic family interests [61]. Many large family-owned firms in Jinjiang considered going public as an important strategy for sustainable growth and a necessary response to increasing competition on traditional product markets. They would make adjustment in corporate governance to satisfy the criteria in specific stock exchanges, such as transformation of corporate system, introduction of new independent directors, removal of some family members without actual benefits, disclosure of financial information, and even environmental requirements. During the interview, 11 firms mentioned that they actively improved the production process during the adjustment of firm organization and system, which promotes the process and product upgrading.

Going public facilitates firm access to advanced factors, including financial resources and professional talents, to expand production scale, and exercise management and technological innovation, with lower costs and higher efficiency. Due to comparatively abundant financial capital, some firms turn to new sectors and realize chain upgrading (for example, A8 entered the video game industry after being listed). When compared with access to financial resources, local firms used to face more difficulties to attract advanced talents, for such talents would not like to work in traditional manufacturers and in such a small city. However, most interviewees agreed that this situation has changed as listed firms emerged. Furthermore, in order to satisfy the requirements from stock exchange markets and to cope with more complex business circumstances, local firms had to invest a lot in a series of internal innovation, such as equipment renewal, business process reengineering, and quality management innovation. Taking A29 as an example. The firm was originally a family-owned firm in textile sector, and introduced advanced management system, Enterprise Resource Planning, to meet the requirement on establishment of transparent and intuitive information mechanism of financial management for going public. As a result, the production process has been simplified and the production efficiency has been enhanced. Its delivery period has been shortened by $20 \%$, and the product cost decreased greatly.

In addition to some requirements on internal management and financial conditions, China's capital market issued regulations of environmental verification for listed firms as early as 2003. Therefore, the firms, especially in the leather industry, are required to make technological innovation to meet these standards in the process of going public. As the lead leather manufacturer in Jinjiang, A35 invested a lot in minimizing its pollution emissions before going public, and eventually developed a new clean production technology, filling gaps in the pollution control of the domestic leather industry. This can be also considered as a process upgrade. Rather than keeping its technology as a secret, A35 shared it with its local peers, and helped them to transform into clean production. 


\subsection{Going Public, Interfirm Relationships and the Upgrading of Local Related Firms}

Going public brings about opportunities for local firms to cooperate with external firms as investors and shareholders; which exerts an effect on the upgrading of S \& A industry. $58 \%$ of the enterprises in the interview clearly mentioned that they faced pressure from investors and shareholders, and those listed firms have to make adjustment in their strategies according to investors' preferences. Investors in different regions may have different preferences, and bring about different effects on industrial upgrading. Six firms mentioned that as investors in the destination of going public have a preference for technological innovation, they were encouraged to speed up technological upgrading to get funds. Going public helps local firms to improve their reputation, which is more conducive to attract domestic and foreign investors. These investors establish a close relationship with firms through the financial channels, such as acquisition of shares of listed firms, and this relationship is an important pipeline for knowledge spread and learning. Tacit knowledge from new shareholders/investors spill over through this pipeline, and combine with original knowledge to be a new one. Firms can take this opportunity to carry out the development strategy to achieve firm upgrading: usually expressed as technology and product upgrading, or the extension of the value chain.

Going public means that firms become transparent in that much corporate information is exposed to the public, which can enhance the attention of global investors and improve the reputation of listed firms [62]. 23 listed firms in the interview mentioned that being a listed firm is a good reputation and made them trustworthy, thus a number of external shareholders and investors would like to visit the firms and then establish strategic cooperative relationship with them. That provides opportunities for listed firms to make upgrading. A31 is a typical example. Before going public, the firm was a manufacturer of traditional textile materials. In 2010, it successfully went public in Hong Kong and achieved good performance, and gained favor of the only energy-saving, state-owned company in China. The state-owned firm eventually acquired A31 in 2012, provided A31 with the necessary funds, as well as technical assistance, quality standards, and personnel training. A31 then turned to produce non-woven materials for environmental protection, and realize the product upgrading. Furthermore, as the partner of the state-owned firms, A31 can indirectly get resources concerning the people's livelihood (such as energy, marine rare materials, etc.), which is difficult for private enterprise to obtain. Consequently, A31 successfully made the transformation from a textile manufacturer to a high-tech material manufacturer and realized chain upgrading. At present, these products not only occupy a large share in the domestic market, but have also been exported to Europe, the United States, Southeast Asia, and other regions, greatly enhancing the status of production networks.

The establishment of cooperative interfirm relations can help firms to achieve knowledge sharing [63], and form a learning pipeline. More than $90 \%$ of listed firms interviewed said that before going public it was difficult for them to obtain updating information and professional knowledge. This situation has been changed after going public. 13 firms claimed that they made an adjustment in corporate strategies based on learning pipelines, enhanced production efficiency and technical level, and achieved an extension of the value chain. Another example is A16. Before going public, it was an indoor sports apparel manufacturer. Similarly, it benefited from the increased reputation of becoming a listed firm. In order to further expand the scale and enter into new sectors, A16 used the identity of listed company to take the initiative to introduce strategic investors, who was familiar with the sports health and Internet application fields and its investment covers the entire health industry chain. Relying on medical and health knowledge and development experience provide by strategic investor and the financial capital acquired by going public, A16 actively absorbs and integrates new knowledge, and takes strategic transformation strategy of original industry to achieve the extension of the industrial value chain, finally completed the chain upgrading from traditional sports clothing manufacturing to health industry.

Jinjiang S \& A firms establish a global channel to enter the international market through overseas listing. Financial standards and other requirements in Chinese capital markets are very stringent for 
private enterprise and are more conducive to state-owned enterprises [55]. Many private Jinjiang enterprises turn to overseas capital markets. According to the interview, only six firms went public in the domestic market, and the rest mainly in Hongkong, Singapore, Malaysia. 24 listed firms mentioned that they got the attention of and established contact with foreign investors by overseas listing. With the help of overseas investors, listed firms can enter the markets with critical demand for high-quality products in developed economies, which were supposed to be very difficult to enter for them. For example, A1 has already had a good brand reputation and market share in China before going public, but has not yet made the expansion to overseas markets. Being listed in Hong Kong in 2007, it soon attracted the owner of the Rockets in the National Basketball Association of the US as its largest overseas shareholder. A18 and A8 have the similar experience of business expansion to advanced countries. Those firms took the chance of going public to make strategic coordination and got the opportunity to increase the market share of their products with their own brands in the domestic and global market, which is an important part of upgrading [64].

Like other traditional industrial clusters in China, S \& A cluster in Jinjiang used to be largely based on kinship and intensive social relations between firms and other organizations [65]. 75\% of listed firms in the interview were the lead firms of their local networks before going public. Their listing and upgrading behaviours have an important demonstration effect on other local firms. Especially, Firm A1 is the pioneer of going public in Jinjiang. It encouraged its peer firms, such as A15, A4, A14, and A22, to go public and recommended its financial council team to them. Other firms, such as A8, A12, did not directly get the help of A1, but A1's success to be listed and rapid growth afterwards stimulated them to make listing plans.

The majority of the listed firms in the interview said that they re-screened local suppliers and contractors after going public for the guarantee of more production efficiency and high-level quality of products, which eventually led to the reconstruction of local production networks. Their increasingly strict requirements for products and services improve the innovation capability of their supplier firms, which consequently leads to the overall technological and industrial upgrading in local S \& A manufacturing. Eight of 14 related firms in the interview mentioned that the technology upgrading and knowledge innovation of listed firms (especially final product suppliers) is an important reason to promote their upgrading. Moreover, the preferences of technology, knowledge, and upgrading from these listed firms also affect the upgrading of related firms. Once the listed firms adopt a new technology or standard, their suppliers and partners have to make change accordingly to maintain the cooperative relationship.

As mentioned before, going public brings about more opportunities for local lead firms to access to advanced factors, which makes these firms act as a technological 'gate keeper'. They transfer new knowledge and technological innovation to other firms through their production networks and local buzz, and promote the upgrading of the S \& A cluster. Listed firms impose pressure on their suppliers to make innovation, and give assistance to them to make intrafirm coordination. Therefore, it is possible for these suppliers to decrease the cost and the risk of technological innovation. A35, a leather manufacturer in S \& A cluster, is a case in point. The firm has begun to implemented green production technology after going public; while its suppliers cannot afford the expense of green technology. A35 proposed the joint implementation of green, environmental transformation, and advised the whole industry in Jinjiang to share the costs of advanced equipment, technology, and raw materials. As a result, the price of the environmentally friendly materials decreased, and local leather firms made upgrading toward green production technology under the leadership of A35. In 2010, the funds that 77 leather firms in Jinjiang invested in pollution prevention and clean technology transformation reached 10 billion Yuan.

Cooperation between listed firms, especially those list firms with long-term strategic targets and the capability of prompt response to changing market circumstances, becomes frequent. Most interviewees put forward that cooperation with listed firms with innovative capabilities can be beneficial to enhance client firms' and (potential) investors' trust, and so as to increase the market 
competitiveness. Figure 2 shows the dynamic relationships between listed firms and their related firms in the local S \& A industry. A16, A19, and A27 were integrated into this network after their going public. A31 and A32 have maintained the partnership with their client firms within this cooperative network for a long time, and they also succeeded in going public.

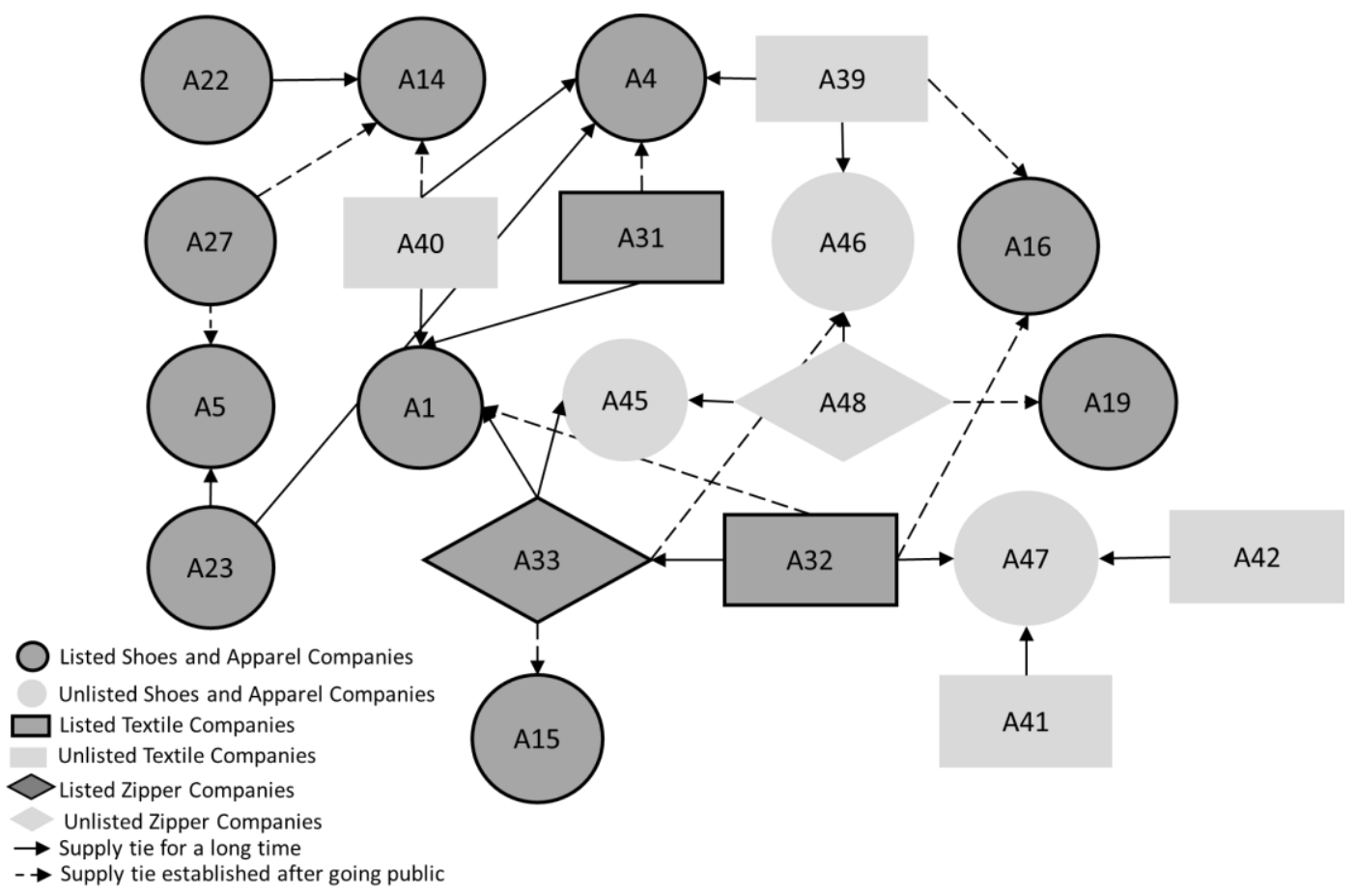

Figure 2. Cooperative network of listed firms in the shoes and apparel (S \& A) manufacturing cluster of Jinjiang.

\subsection{Going Public, Extrafirm Bargaining, and Local Industrial Upgrading}

\subsubsection{Going Public as Local Development Strategy Jointly Initiated by Local Government and Firms}

More than $80 \%$ firms in the interview affirmed the role of local government in the process of going public. The emerging Jinjiang Board in the domestic and foreign stock market is attributed to the strategic intents of local firms, and it is also the result of the guidance of the local government. Local government initiatively makes great contributions to the burgeoning of listed firms. The government has created a policy environment that encourages firms in going public, such as giving subsidies for firms. For example, the local government has set up a "specific fund for the development of listed firms" in 2007, and firms can get two to three million Yuan after going public, as to help solve the problem of capital deficiency. Local government also carries out targeted training programs in 2009, by the establishment of a professional service group with the assistance of 21 institutions, including eight securities firms, four accounting firms, five law firms, two asset evaluation firms, two investment institutions, and several international companies, such as Merrill Lynch, the Hong Kong and Shanghai Banking Corporation, and KPMG, etc. In addition, the government also provides price competitiveness of infrastructure such as land, water, and electricity only for listed firms.

The motivations for local government to promote local firms to go public are multiple. Firstly, the number of listed firms is considered as an indicator of regional economic prosperity and a measurement of administrative performance for local governments, and it is often the key to career promotion for local officials. Secondly, the increasing number of potential listed firms would increase local fiscal revenue, which is also an important reason for the local government to encourage local firms to go public at home and abroad. Almost all of the interviewees respond that the largest 
proportion of increased costs after going public is related to tax payment. Listed firms provided taxes of more than four billion yuan in 2014, nearly accounting for a quarter of all the taxes in Jinjiang. Furthermore, promoting the transformation and upgrading of the local industrial clusters in Jinjiang is another important reason for local government to encourage local firms to go public. A number of traditional firms faced difficulties in business expansion for shortage of financial capital and problems of management system as family-owned firms. Under such circumstances, local government put forward a capital operation plan in 2001, and took going public as an effective strategy to cultivate lead firms, which can further strengthen regional competitiveness and promote industrial upgrading.

Going public increases the bargaining power of local firms to local government, and they can obtain more local scarce resources, such as land parcel in a good location. According to the interview, listed firms have the priority over ordinary firms when biding the same land parcel. To keep listed firms in Jinjiang from migrating their high-value-added activities to other cities, local government stimulates listed firms in upgrading in the local. In 2011, local government set up an industrial park for listed firms to satisfy their demand for land resources for business expansion, to drive listed firms and their local suppliers to improve product quality, and to realize product upgrading. Besides, in 2014, local government put forward some encouragement policies to inspire innovation of lead firms, through connection to professional services providers, universities, and research institutes.

With the guidance of the government, listed firms have brought about return investments in innovation projects in Jinjiang. In the first ten months of 2010, there were 13 return investment projects, with a total investment of 318 million US dollars, accounting for $42.5 \%$ of the total foreign investment in Jinjiang. Most investments aimed at equipment renewal and technological transformation projects, which has improved the overall competitiveness of firms and the upgrading of regional industries.

\subsubsection{Going Public, Agglomeration of Financial Institutions, and Local Burgeoning Producer Services}

As the number of listed firms increases, Jinjiang has established and maintained a close relationship with external financial institutions, including domestic and foreign investment banks, private equity institutions, law offices, and accounting firms. Due to a high level of economic performance of listed firms and high-quality small and medium enterprises (SMEs) in Jinjiang, these financial institutions and other producer service firms, such as Tianjin Equity Exchange, Daosheng Shares, and China Science \& Merchants Investment Management Group, have established branch offices there. In addition, stock exchanges and investment banks at home and abroad, including Shanghai Stock Exchange, Shenzhen Stock Exchange, Hong Kong Stock Exchange, and Singapore Stock Exchange, have also cooperated with local government, providing a variety of services for local firms, including training guidance of going public and facilitating to lower the censorship threshold in specific listing destination.

The increasing agglomeration of financial institutions in Jinjiang brings about frequent cooperation between manufacturing firms and financial sectors, and the knowledge spillover from financial institutions. As a consequence, a great proportion of listed firms have engaged in capital investment, which stimulates the prosperity of local quasi-financial and financial services, such as loans, guarantees, pawning, financial services, and capital management, etc. As local financing capability improves, local firms get more easy access to financial resources with less cost than before. The first venture capital firm in Jinjiang, Hongqiao Venture, was established in 2007 as a joint achievement of A19 and several well-developed listed firms, to help local SMEs to go public. With its help, additional industrial capital of more than seven billion yuan in total entered the local (quasi) financial sector in 2015, and 61 private financial institutions and quasi-financial institutions were founded in Jinjiang. This leads to the prosperity of capital-intensive and services industries, and Jinjiang has been making the transformation from manufacturing-dominating economy towards a service-dominating economy. 


\subsection{The Risks of Going Public}

Although going public brings many benefits for firms and local S \& A industry, there are also some risks and a couple of failure cases in Jinjiang.

Above all, going public causes local firms to be exposed to strict financial and business audits. As mentioned before, the majority of these firms were family-owned before going public, and their financial and business systems hardly met the requirements of the stock exchange, and need to be adjusted accordingly. This process is costly and time-consuming, and some firms failed to do so. Because of some 'loopholes', many firms carried out some practices, such as financial fraud and capital manoeuvres, during their preparation for being listed. Some firms faced the risk of paying heavy taxes in arrears, and the exposure of false lending during the scrutiny of the listing process. This caused great financial pressure and a bad name for these firms. Therefore, a couple of firms gave up their going public plan later. A49 is a typical case. It took the firm nearly seven years and cost a huge amount of capital to prepare for going public domestically, but the listing process was terminated as a result of its concealment of business matters. A49 was bankrupt and taken over in the end.

Besides, without a clear strategic object and the capabilities of intrafirm coordination, some firms not only failed to take the opportunity to strengthen their competitiveness after going public, but also were easily exposed to increasingly serious market competition. As a consequence, they encountered a business crisis. For example, A5, a firm listed in the United States, made use of the 700 million yuan raised on the stock market to make an expansion to low-quality products rather than to strengthen its global competitiveness based on innovation and upgrading. Eventually, it experienced a rapid decline in economic performance and had to be delisted and bankrupted. These failure experiences in Jinjiang also prove that going public is not guaranteed to strengthen a firm's competitiveness and benefit local industrial upgrading. Only appropriate strategic adjustments, such as intra-firm innovation and technological upgrading, or the reconstruction of inter-firm and extra-frim relationships, make it possible for a firm to achieve sustainable development after going public.

\section{Conclusion and Discussion}

Extant literature considers that integration into GPN as offshoring manufacturing destinations provides business opportunities, technological accumulation, and knowledge learning for local firms in developing countries, but pays little attention to the financial activities of lead firms in those countries and their effects on local development. This article provides a case to industrial upgrading with financial activities, which is one of its contributions to industrial upgrading research. The case of Jinjiang shows that, with the development of financial globalization, local lead firms in developing countries have been increasingly involved in the global financial market by going public, which in turn provides these countries with opportunities of industrial upgrading. Therefore, not only finance should be integrated into GPN theory, as some scholars suggest $[17,24]$, but also the impacts of local lead firms in developing countries on the dynamics or reconfiguration of GPN should be taken consideration, especially in some specific sectors. That is another contribution of this article to the industrial upgrading and GPN research. Besides, unlike the fact that extant research focuses on national scale, this article explores industrial upgrading under the context of local clusters.

Preliminary findings indicate that going public, as an initiative strategy with a response to the increasing market competition, facilitates local firms access to financial capital and other scarce resources, and provides them with external learning pipelines for sustainable development. However, it does not necessarily guarantee industrial upgrading, due to potential risks, for example. From the perspective of the GNP 2.0 framework, whether or not going public can trigger industrial upgrading depends mainly on intrafirm coordination, reconfiguration of interfirm relationships, and extrafirm bargaining. First of all, going public makes local firms exposed to increasingly complex circumstances, and they have to make intrafirm coordination in order to meet the requirements of the stock exchange and investors' preferences. In the case of Jinjiang, local lead firms aims to combat with global leaders in the markets at home and abroad, especially the markets of advanced countries with 
high-quality taste. They take advantages of advanced factors, such as financial capital, and professional talents, which are accessible after going public, to improve the competitiveness of the products with their own brands, instead of remaining as suppliers in the global value chain of MNCs. Secondly, going public promotes local firms to build up cooperative relationships with external investors and shareholders, which gives pressure for listed firms to make innovation so as to improve the level of economic profits, and at the same time provides them with channels to access to the markets with high quality demands, financial capital, and learning pipelines to realize upgrading in their original sectors and make a successful expansion to new and high technological industries. Those innovative listed firms also act as technological gatekeepers in the local cluster, and transfer knowledge and innovation to their local partners by reconfiguring their local industrial networks. As a result, the local industrial upgrading has been turned into reality. Thirdly, in the institutional context of China, local governments play an indispensable role in local development. Local governmental officials have initiatives to provide public facilities and services for local firms to successfully go public and make innovation, which improves their political achievements and get promotion. Increasing bargaining power with local governments facilitates local firms access to local scarce resources, and financial and nonfinancial supports.

This article is an explosive research, and there are still some defects and issues deserving further discussion. First, industrial upgrading is a dynamic and complex process. Especially, going public causes local development to be increasingly affected by external investors, which means that local industry faces more uncertainty than before. Therefore, it requires further observation for a long period. Second, different firms have different choices for the listing destinations, such as in domestic or overseas stock markets, and the different characteristics and preferences of investors from different places may cause different effects on industrial upgrading. It is worth further exploration. Moreover, it needs more details in the effects of intrafirm coordination, interfirm relationships, and bargaining with other agencies on the reconfiguration of production networks of listed firms and then on the industrial upgrading. Besides, in the field survey, the authors noticed that some firms have the intention to move to large cities before or after going public. What are the effects on the upgrading of local clusters needs further attention.

Acknowledgments: This research is supported by the National Natural Science Foundation of China (project code: 41171098). The authors would also wish to extend their thanks to two anonymous reviewers, Karen P.Y. Lai at National University of Singapore, and Fenghua Pan at Beijing Normal University of China for their valuable comments, and to all the interviewees for their responses and time.

Author Contributions: Zhu Huasheng contributed to the conceptual framework of the paper; Ding Yue contributed to the fieldwork.

Conflicts of Interest: The authors declare no conflicts of interest.

\section{References}

1. China Becomes the World's Leading Manufacturer. Available online: https:/ / search.proquest.com/docview/ 862373722? accountid=8554 (accessed on 14 November 2017).

2. Gereffi, G. International trade and industrial upgrading in the apparel commodity chain. J. Int. Econ. 1999, 48, 37-70. [CrossRef]

3. Poon, S.C. Beyond the global production networks: A case of further upgrading of Taiwans information technology industry. Int. J. Technol. Glob. 2004, 1, 130-144. [CrossRef]

4. Brandt, L.; Thun, E. The Fight for the Middle: Upgrading, Competition, and Industrial Development in China. World Dev. 2010, 38, 1555-1574. [CrossRef]

5. Hansen, U.E.; Fold, N.; Hansen, T. Upgrading to lead firm position via international acquisition: Learning from the global biomass power plant industry. J. Econ. Geogr. 2014, 16, 131-153. [CrossRef]

6. Ernst, D.; Kim, L. Global production networks, knowledge diffusion, and local capability formation. Res. Policy 2001, 28, 76-78. 
7. Humphrey, J.; Schmitz, H. Governance and upgrading: Linking industrial cluster and global value chain research. Local Enterp. Glob. Econ. 2004, 29, 349-381.

8. $\mathrm{Xu}, \mathrm{R}$. Research of Industrial Upgrading Basing on Industrial Technology Chain. In Proceedings of the 2015 2nd International Conference on Industrial Economics System and Industrial Security Engineering, Singapore, 11 December 2015; Li, M., Zhang, Q., Zhang, J., Li, Y., Eds.; Springer: Singapore, 2015; pp. $135-140$.

9. Benfratello, L.; Schiantarelli, F.; Sembenelli, A. Banks and innovation: Microeconometric evidence on Italian firms. J. Financ. Econ. 2008, 90, 197-217. [CrossRef]

10. Amendola, M.; Gaffard, J.L.; Musso, P. Innovation and Competition: The Role of Finance Constraints in a Duopoly Case. Rev. Austrian Econ. 2003, 16, 183-204. [CrossRef]

11. Liu, W.C.; Hsu, C.M. The role of financial development in economic growth: The experiences of Taiwan, Korea, and Japan. J. Asian Econ. 2006, 17, 667-690. [CrossRef]

12. Okuda, H.; Take, Y. Economic Reforms and Financing Structure of Indonesian Listed Companies after the Asian Crisis: Corporate Finance Issues and the Solutions. JBICI Rev. 2005, 12, 1-31.

13. Milberg, W.; Winkler, D. Outsourcing Economics: Global Value Chains in Capitalist Development; Cambridge University Press: Cambridge, MA, USA, 2013; Volume 67, pp. 268-269.

14. Pike, A. 'Shareholder value' versus the regions: The closure of the Vaux Brewery in Sunderland. J. Econ. Geogr. 2006, 6, 201-222. [CrossRef]

15. Pan, F. Insertion into Global Capital Networks: An Alternative Way for the Upgrading of Industrial Clusters. In Proceedings of the Annual Meeting of the Associations of American Geographers, Los Angeles, CA, USA, 8-13 April 2013.

16. Balas, N.; Palpacuer, F. Financialization of Global Value Chains and Implications for Local Development. In Finance and Industrial Policy; Oxford University Press: New York, NY, USA, 2016; pp. 65-80.

17. Yeung, W.C.; Coe, N.M. Toward a dynamic theory of global production networks. Econ. Geogr. 2015, 91, 29-58. [CrossRef]

18. Ernst, D. Globalization and the Changing Geography of Innovation Systems. A Policy Perspective on Global Production Networks. In Proceedings of the International Workshop: The Political Economy of Technology in Developing Countries, Brighton, UK, 8-9 October 1999.

19. Henderson, J.; Dicken, P.; Hess, M.; Coe, N.; Yeung, H.W.-C. Global production networks and the analysis of economic development. Rev. Int. Political Econ. 2002, 9, 436-464. [CrossRef]

20. Humphrey, J.; Schmitz, H. Chain governance and upgrading: Taking stock. In Local Enterprises in the Global Economy: Issues of Governance and Up-Grading; Edward Elgar: Cheltenham, UK, 2004; pp. 349-381.

21. Gereffi, G. The governance of global value chain. Rev. Int. Political Econ. 2005, 12, 78-104. [CrossRef]

22. Wei, Y.H.D. Beyond the GPN-new regionalism divide in China: Restructuring the clothing industry, remaking the Wenzhou model. Geogr. Ann. 2011, 93, 237-251. [CrossRef]

23. Coe, N.M. Geographies of Production II: A Global Production Network A-Z. Prog. Hum. Geogr. 2012, 36, 389-402. [CrossRef]

24. Coe, N.M.; Lai, K.P.Y.; Wójcik, D. Integrating Finance into Global Production Networks. Reg. Stud. 2014, 48, 761-777. [CrossRef]

25. Karel, W. From shareholder value to present-day capitalism. Econ. Soc. 2000, 29, 1-12.

26. William, M. Shifting sources and uses of profits: Sustaining US financialization with global value chains. Econ. Soc. 2008, 37, 420-451.

27. Humphrey, J.; Schmitz, H. Governance and Upgrading in Global Value Chains; Paper for the Bellagio Value Chain Workshop; Institute of Development Studies University of Sussex: Brighton, UK, 2000.

28. Kaplinsky, R.; Morris, M. A Handbook for Value Chain Research; IDRC: Ottawa, ON, Canada, 2001.

29. Porter, M.E. The Competitive Advantage of Nations; Macmillan: London, UK, 1990.

30. Krippner, G.R. Capitalizing on Crisis: The Political Origins of the Rise of Finance; Harvard University Press: Cambridge, MA, USA, 2011.

31. Moore, C.B.; Bell, R.G.; Filatotchev, I.; Rasheed, A.A. Foreign IPO capital market choice: Understanding the institutional fit of corporate governance. Strateg. Manag. J. 2012, 33, 914-937. [CrossRef]

32. Chun, H.; Kim, J.W.; Morck, R.; Yeung, B. Creative destruction and firm-specific performance heterogeneity. J. Financ. Econ. 2008, 89, 109-135. [CrossRef]

33. Blundell, R.; Griffith, R.; van Reenen, J. Market Share, Market Value and Innovation in a Panel of British Manufacturing Firms. Rev. Econ. Stud. 1999, 66, 529-554. [CrossRef] 
34. Pastor, L.; Veronesi, P. Technological Revolutions and Stock Prices. Cepr Discuss. Pap. 2005, 99, 1451-1483.

35. Lall, S. Technological capabilities and industrialization. World Dev. 1992, 20, 165-186. [CrossRef]

36. Zhang, C.; Bank, W. Promoting Enterprise-Led Innovation in China; World Bank Publications: Washington, DC, USA, 2009; pp. 1-142.

37. Makadok, R. Towards a synthesis of resource-based and dynamic capability views of rent creation. Strateg. Manag. J. 2001, 22, 387-402. [CrossRef]

38. Barney, J. Firm resources and sustained competitive advantage. J. Manag. 1991, 17, 99-120. [CrossRef]

39. Teece, D.J.; Pisano, G.; Shuen, A. Dynamic capabilities and strategic Management. Strateg. Manag. J. 1997, 18, 509-533. [CrossRef]

40. Ahuja, G. The Duality of Collaboration: Inducements and Opportunities in the Formation of Interfirm Linkages. Strateg. Manag. J. 2000, 21, 317-343. [CrossRef]

41. Brainard, S.L. An Empirical Assessment of the Proximity-Concentration Trade-off Between Multinational Sales and Trade. Am. Econ. Rev. 1997, 87, 520-544.

42. Pan, F.; Brooker, D. Going global? Examining the geography of Chinese firms' overseas listings on international stock exchanges. Geoforum 2014, 52, 1-11. [CrossRef]

43. Ruan, J.; Zhang, X. Finance and cluster-based industrial development in China. Econ. Dev. Cult. Chang. 2009, 58, 143-164. [CrossRef]

44. Ruan, J.; Zhang, X. Credit constraints, clustering, and profitability among Chinese firms. Strateg. Chang. 2012, 21, 159-178. [CrossRef]

45. Oyer, P.; Schaefer, S. Why do some firms give stock options to all employees? An empirical examination of alternative theories. J. Financ. Econ. 2004, 76, 99-133. [CrossRef]

46. Stokman, F.N.; Knoop, J.V.D.; Wasseur, F.W. Interlocks in the Netherlands: Stability and careers in the period 1960-1980. Soc. Netw. 1990, 10, 183-208. [CrossRef]

47. Florida, R.L.; Kenney, M. Venture Capital, High Technology and Regional Development. Soc. Sci. Electron. Publ. 1988, 22, 3-48. [CrossRef]

48. Qing, X.; Zeng, Y.; Li, J. Listing channel and cause analysis of private enterprises. Manag. Sci. 2008, 5, 443-452, 486. (In Chinese)

49. Yao, S.; Meng, D. From passive embedding to self construction of global production network: A case study of Taiwan computer industry. Sci. Econ. Soc. 2014, 32, 81-85. (In Chinese)

50. Horner, R. Strategic decoupling, recoupling and global production networks: India's pharmaceutical industry. J. Econ. Geogr. 2014, 14, 1117-1140. [CrossRef]

51. Li, P.F. Horizontal versus vertical learning: Divergence and diversification of lead firms in the hangji toothbrush cluster, China. Reg. Stud. 2014, 48, 1227-1241. [CrossRef]

52. Bathelt, H.; Glückler, J. Netzwerke, lernen und evolutionäre regionalentwicklung. Z. Für Wirtsch. 2000, 44, 167-182. [CrossRef]

53. Zhu, H.; Chen, K.W.; Dai, J. Beyond Apprenticeship: Knowledge Brokers and Sustainability of Apprentice-Based Clusters. Sustainability 2016, 8, 1279. [CrossRef]

54. Bathelt, H.; Malmberg, A.; Maskell, P. Clusters and knowledge: Local buzz, global pipelines and the process of knowledge creation. Prog. Hum. Geogr. 2004, 28, 31-56. [CrossRef]

55. Du, J.; Xu, C. Which Firms went Public in China? A Study of Financial Market Regulation. World Dev. 2009, 37, 812-824. [CrossRef]

56. Schmitz, H. Global competition and local cooperation: Success and failure in the Sinos Valley, Brazil. World Dev. 1999, 27, 1627-1650. [CrossRef]

57. Lee, E.; Walker, M.; Zeng, C. Do Chinese government subsidies affect firm value? Account. Org. Soc. 2014, 39, 149-169. [CrossRef]

58. Piotroski, J.D.; Zhang, T. Politicians and the IPO decision: The impact of impending political promotions on IPO activity in China. J. Financ. Econ. 2014, 111, 111-136. [CrossRef]

59. Gereffi, G. The Global economy: Organization, governance and development. In The Handbook of Economic Sociology, 2nd ed.; Smelser, N.J., Swedberg, R., Eds.; Princeton University Press/Russell Sage Foundation: Princeton, NJ, USA, 2005; pp. 160-182.

60. Tokatli, N. Toward a better understanding of the apparel industry: A critique of the upgrading literature. J. Econ. Geogr. 2012, 13, 993-1011. [CrossRef] 
61. Anderson, R.C.; Reeb, D.M. Founding-family ownership and firm performance: Evidence from the S \& P 500. J. Financ. 2003, 58, 1301-1327.

62. Pagano, M.; Röell, A.A.; Zechner, J. The geography of equity listing: Why do companies list abroad? J. Financ. 2002, 57, 2651-2694. [CrossRef]

63. Dhanaraj, C.; Tihanyi, L. Managing tacit and explicit knowledge transfer in IJVs: The role of relational embeddedness and the impact on performance. J. Int. Bus. Stud. 2004, 35, 428-442. [CrossRef]

64. Humphrey, J.; Schmitz, H. How does insertion in global value chains affect upgrading in industrial clusters? Reg. Stud. 2002, 36, 1017-1027. [CrossRef]

65. Granovetter, M. Economic action and social structure: The problem of embeddedness. Am. J. Sociol. 1985, 91, 481-510. [CrossRef]

(C) 2017 by the authors. Licensee MDPI, Basel, Switzerland. This article is an open access article distributed under the terms and conditions of the Creative Commons Attribution (CC BY) license (http:/ / creativecommons.org/licenses/by/4.0/). 